PREGLEDNI RAD

UDK: 339-133.3:<061.6:004>

Hrvoje Jošić, Ph.D. *

Antea Barišić, mag. oec. **

\title{
APPLE INDICES AS A NEW INFORMAL MEASURE OF PURCHASING POWER PARITY
}

\author{
APPLEOVI INDEKSI KAO NOVI NEFORMALAN NAČIN \\ MJERENJA PARITETA KUPOVNE MOĆI
}

\begin{abstract}
This paper examines the validity of the Purchasing Power Parity (PPP) theory, using 12 different single-product baskets of Apple devices. Given the presented advantages of Apple indices as PPP measurement in comparison to the most prominent informal index- the Big Mac index (BMI), they are therefore pointed out to be more adequate modern measures of PPP. Presented study investigates if the theory holds for different products within the same niche across 37 countries. Furthermore, this paper presents results of cross country ordinary least squares (OLS) regression analysis of the data for 6 different Apple products. Results point out that most-favoured nation (MFN) duty rates and sales taxes together with additional duties and taxes are main factors that affect currency valuation against the U.S. dollar. In contrary to BMI, Apple indices indicate real undervaluation of most of the national currencies against the U.S. dollar and have also shown to be more supportive to the PPP validity than the BMI.
\end{abstract}

KEY WORDS: Law of one price, Purchasing power parity theory, Apple indices, Big Mac index.

SAŽETAK: Ovaj članak ispituje valjanost teorije pariteta kupovne moći (PPP) koristeći 12 različitih proizvoda iz košarice Appleovih proizvoda. S obzirom na izložene prednosti Appleovih indeksa prilikom mjerenja PPP u usporedbi s najistaknutijim neformalnim indeksom - Big Mac indeksom (BMI), Appleovi indeksi se ističu kao prikladnija modernija verzija mjere pariteta kupovne moći. Predstavljena studija istražuje valjanost navedene tvrdnje koristeći različite proizvode unutar iste niše za 37 zemalja koristeći metodu najmanjih kvadrata (OLS) regresijske analize na podacima za 6 različitih Appleovih proizvoda. Rezultati analize ukazuju da su carinske stope utvrđene po načelu najpovlaštenije države (MFN) i stope poreza na promet zajedno s dodatnim pristojbama i porezima glavni

Hrvoje Jošić, Ph.D., Assistant Professor, Department of International Economics, Faculty of Economics and Business, University of Zagreb, Trg J. F. Kennedyja 6, HR-10000 Zagreb, Croatia, hjosic@efzg.hr. Antea Barišić, MA, Assistant, Department of International Economics, Faculty of Economics and Business, University of Zagreb, Trg J. F. Kennedyja 6, HR-10000 Zagreb, Croatia, abarisic@net.efzg.hr. 
čimbenici koji utječu na vrijednost valute prema američkome dolaru. Nasuprot BMI, Apple indeksi ukazuju na realnu podcijenjenost većine nacionalnih valuta prema američkome dolaru i također su pokazali da više podržavaju valjanost PPP-a od BMI-a.

KLJUČNE RIJEČI: zakon jedne cijene, teorija pariteta kupovne moći, Appleovi indeksi, Big Mac indeks.

JEL: F31

\section{INTRODUCTION}

Purchasing power parity (PPP) theory through aggregating the law of one price (LOP) points out that due to arbitrage between different markets, all identical goods and services should be sold at the same price when converted into a common currency. Following, as proposed by Cassel in 1918, exchange rates should be determined "by the quotient between general levels of prices in two countries" (Balassa, 1964).

PPP rates based on the consumer price index (CPI) are most frequently used by international financial institutions to calculate and report PPP based GDP and GDP per capita in common currency and make comparisons across countries to point out their real economic performances, size of the economy, level of development and wellbeing of their residents. Additionally, companies holding international portfolios use it as international asset allocator, to forecast exchange rates and calculate it in their investments figures (Annaert and De Custer, 1997). On the other side employees of multinational companies use it for planning their expatriate engagements, the same as other potential economic migrants checking the appropriate salary packages in different countries. Making PPP one of the most important denominators in the international economy enabling comparisons among the countries around the globe has given this topic significant amount of research since its foundations made more than 100 years ago.

Differences in consumer preferences across countries and biases towards certain goods, its qualities and contents, makes it hard to find a common basket of comparable goods for CPI calculation of the PPP. Due to that, while striving to compare exactly the same goods to test the theory with its true postulates, several informal single-good basket measures have emerged. The most widely accepted one, published semi-annually by The Economist is the Big Mac index (BMI), celebrating 30 years of publishing. This light-hearted measure of PPP, due to its consistency on different locations and time, was upon its rise praised to be an easy and good way of currency valuation, while afterwards different researches pointed out its several limitations, mostly regarding tradability of the product itself, its ingredients characteristics and the portion of non-tradable elements in its price. Due to fact that McDonald's in Africa operates only in Morocco, Egypt and South Africa, equivalent KFC index has emerged and is being calculated for 20 African countries. ${ }^{1}$ Starbucks latte price around the world was also presented by The Economist in 2004 as Starbucks index comparing 16 different markets at the time, but was not so widely accepted and has not been published ever since. ${ }^{2}$ Lately introduced informal measure of PPP considering

Available at: http://sagaciresearch.com/kfcindex/.

Available at: http://www.economist.com/node/2361072 . 
Apple products prices is calculated by Australian CommSec on yearly basis. It emerged in 2007 as iPod index and afterwards was followed by iPad and iPhone indices.

Although a vast theoretical and empirical literature is present on PPP and as well on the BMI, indices of Apple products still haven't been investigated by the scholars and it is almost not existing. Given the downsides of the BMI which are in common with KFC and mostly with Starbucks index, this study points out advantages of using Apple index based on the prices of 12 different Apple products, as a measure of over/undervaluation of a currency and tests the PPP in the light of this new instrument. While pointing out the main characteristics of Apple products indices in comparison to BMI index, calculation of their figures points out to their contrary findings in the context of 21th century, using dollar, still the most important currency in the foreign trade, as the base currency.

Following the theoretical framework of the underlying theories of LOP and PPP in the second chapter, research overview in the third chapter points out to main findings within the BMI literature. Fourth chapter proposes novel measures of PPP and discusses differences between newly proposed Apple indices and BMI. Fifth chapter gives the results of testing the PPP theory using Apple indices, while putting it against BMI and the last chapter points out main research conclusions.

\section{THE LAW OF ONE PRICE AND PURCHASING POWER PARITY THEORY}

International trade theory postulates that when assuming absence of transport costs, different trade restrictions, duties and other legal barriers, as well as central bank interventions, arbitrage should ensure that prices of homogeneous products in different countries are on the same level or to say exactly the same when expressed in a common currency units (Isard, 1977). Arbitrage influence is argued to be relevant at least in the long run, equalizing the prices internationally and ensuring that PPP holds and as well as a necessary condition of the determination of exchange rates in the short run (Ardeni, 1989). According to the LOP for any good $i$ following equation should be true:

$$
P_{i}=E \cdot P_{i}^{*}
$$

$P_{i}$ in the equation stands for domestic-currency price of the good while $E$ stands for exchange rate defined as the home-currency price of foreign currency and $P_{i}^{*}$ is the foreign-currency price of the same good (Rogoff, 1996).

Generalizing the LOP, Cassel was the first to take the PPP theory as a practical empirical theory and give it the name that still holds, although even in 16th century some Salamancan scholars constructed similar discussions. Since Cassel's conceptualization of the PPP theory in 1918 a broad array of different research and empirical studies evolved, engaging many scholars in discussions and research of this topic, giving different perspectives within different historical eras and monetary regimes, from Golden standard, the First and Second World War and Bretton Woods agreement to floating exchange rate regimes. Cassel's definition of PPP is widely known as absolute PPP, which puts national against foreign prices and states that "nominal exchange rate between two currencies should be equal to the ratio of aggregate price levels between the two countries" (Taylor and Taylor, 2004). 


$$
E_{t}^{B}=\frac{P_{t}^{A}}{P_{t}^{B}}
$$

Through generalising the LOP for same goods on national levels with the present arbitrage (Chen et al., 2007) it points out that exchange rates should move towards identical basket of goods and services in all countries (Haidar, 2011). In case the parity does not hold true, arbitrage should channel the converging to parity, and due to that deviations should be minimum. This underlines the connection of countries through prices of tradable goods that are traded between them as one of the doctrine foundations (Officer, 1976).

This widely explored topic reached several empirical findings pointing out that this postulate, in its most strict manner, does not hold in reality. Nevertheless, wide theoretical grounding with these underlying assumptions has developed ever since. In models where traded and non-traded goods are separated, deviations are expected for non-traded goods. Possible high costs of arbitrage and influence of institutional price setting factors make the parity arguable in empirical studies (Ardeni, 1989). Parsley and Wei (1996) as well as several other scholars after them argue that tradable goods including perishable and non perishable goods converge quickly to price parity. Also, Okun et al. (1975) distinct between "customer goods" which are manufactured goods mostly with sticky prices and "auction goods" which are basic commodities with flexible prices.

The PPP can be calculated and applied in different ways. Most common way to calculate it is as an index comparing baskets of goods - consumer price index (CPI). Balassa (1964) pointed out the index number problem, emphasizing the differences in productive endowments and tastes which significantly impact results, as depending on the choice of weights of the chosen goods across different countries. Not all the prices in the economy are included in the CPI. Given the weighted averages of individual prices with different and changing weighs across countries due to varying tastes and consumer preferences makes the cross-country comparisons not absolutely legitimate.

Relative PPP, less strict than the absolute version, states that change in the foreign exchange rate should imply the same change of the consumer prices in both countries at the same time, and moreover that this should be regarded as synonym (Ong, 2003). Ideal base period would be that in which the absolute PPP is true and ratio of prices equals to exchange rate.

$$
\% \Delta e=\% \Delta P^{*}-\% \Delta P^{\$}
$$

Constant foreign exchange rate implies that the ratio of prices between two countries has not changed. Relative and absolute PPP would be the same only in the case of same inflation (current vs. base period) in both countries.

\section{EVOLUTION OF BURGERECONOMICS}

PPP has been largely explored field, raising different discussions and opposing evidence, with ebbs and flows over the period, while aiming to assure comparison among national economies and predicting the future exchange rate direction. As Samuelson and Balassa (1964) and other researchers pointed out transport costs and impediments such as 
quotas, ad valorem tariffs, information costs, taxes and other non-legal barriers exist in the reality, making this theory fail in the short run. According to classical dichotomy, variances in aggregate real exchange rates should be regarded to non - traded goods which do not obey the LOP (Crucini and Landry, 2012). Researchers also pointed out that commodity price arbitrage isn't always the case either in the long run as well, indicating influence of institutional factors on price settings on different markets as well as possible high arbitrage costs (Ardeni, 1989). Besides that, as Krugman pointed out, pricing to market could have a significant impact on similar product prices across countries, when considering products that are not fully opened to arbitrage and with demand not fully elastic, as a way to increase profit. Also non-tradable items, included in tradable products such as wages and utilities, substantially increase prices of many of the tradable products.

Besides the CPI, several informal measurements emerged, reducing the basket of goods to single-good basket representing the national price levels. Research of informal measures of PPP such as BMI, Starbucks index, KFC index and Apple products indices, strives to reveal an easy way of the calculation, at the same time minimizing the CPI methodological problem of consumers' biased tastes.

The BMI compares Big Mac prices across different countries around the world and measures whether currencies are traded at the right exchange rates against the US dollar, which we today call the Raw BMI. ${ }^{3}$ Following the PPP, it is argued that nominal currency exchange rate should reflect the fact that hamburgers cost the same everywhere around the world. Due to its consistency over time and countries the Big Mac was praised to be an easy way of currency valuation, while afterwards different researches pointed out to its several limitations, mostly regarding to the fact that the product itself is not tradable but its ingredients, it is perishable and its price contains significant portion of non-tradable elements, such as wages, rents and utilities but also pricing to market in different cultural surroundings. Different studies give diverse cost ponders of the inputs to the final product of the Big Mac. While Pakko and Pollard (1996) and Soo (2016) find out that only 6-7 percent of Big Mac price can be tied to its tradable components, some other studies pointed out that it goes up to 36-45 percent (Parsley and Wei, 2007) of the total cost.

Nevertheless, both numbers are significant and cast doubt on the index in obeying the underlying laws. These non-tradable components affect the overvaluation of currencies in high income countries, what incentivized development of the adjusted BMI. After considering cheaper prices in poor and developing countries in 2011 The Economist introduced the Adjusted BMI, calculating the difference between actual Big Mac prices and predicted prices according to countries GDP per capita and pointing out the level of misfit to exchange rate with taking into account the country's level of development.

Both indices are published on semi-annual basis for 48 countries (and currencies including the EU) and used as suggestive idea of the currency under/overvaluation against the US dollar. Some researches point to the fact that deviations from BM parity are more strongly associated with changes in relative prices than in exchange rates. Cumby's findings implies that although there are substantial variations from the Big Mac Parity, deviations from relative Big Mac Parity are only temporary and last up to one year in comparison to

Available at: http://www.economist.com/news/business-and-finance/21639762-our-article-1986-introducing-big-mac-index-origins-hamburger-standard. 
the PPP calculations based on the CPI where this happens in 4 to 5 years and in that way this could be a better way of forecasting the future exchange rate (Cumby, 1996).

Besides raw and adjusted BMI, The Economist also used to present GDP per capita expressed in number of Big Macs that each citizen could buy, showing the size of economies. The Big Mac affordability index revealed that the cheap prices of Big Mac do not directly correspond to country's GDP per capita (Atal, 2014).

Besides previously mentioned non-tradable components there are also other components depending on the culture and tastes of the people at each point of sale. McDonald's is in several countries called differently to fit better in the culture and also it sometimes uses different ingredients to customize it to local demand (Pakko and Pollard, 2003). Furthermore, it brings diverse experience across countries and depending on the imperfect competition with no close substitutes (Pakko and Pollard, 1996) and position and strength of the brand on the local market, there could be significant pricing to market possibilities, in case the demand is inelastic. Also, marketing costs built in the burger price, can differ significantly across countries. Although productivity is argued not to be relevant in this case due to workers job description with no significant differences across countries, some researches have shown that less productive countries have undervalued currencies and additionally that countries more opened to trade show less deviations from BMI parity ( $\mathrm{Da}$ Silva et al., 2004).

\section{APPLE INDICES TACKLING THE PPP PUZZLE}

Given the 30 years of literature on exploring the BMI, showing its advantages and shortcomings, it could be time for PPP testing in the 21st century to turn to products which are more aligned to the postulates of the authentic PPP theory. More than 20 years after the introduction of BMI, in January 2007, CommSec Australia introduced iPod index as a first Apple index used to indicate evaluation of currencies and its fit to PPP. Next, with the popularization of other Apple products and modern trends, CommSec shifted to iPad and iPhone indices, while still calculating the firstly introduced one. Mentioned Apple indices still haven't been explored widely, both theoretically and empirically. Mazumder (2016) gave an introduction for this topic, but detailed argumentation and testing are yet to be made to show the figures in the comparable periods and on wider scale of products and give a more detailed analysis of Apple indices advantages. Checking the validity of the BMI and Apple indices as measures of PPP are showing the fit with a single good basket and for sure are not to be taken completely true as not reflecting all prices in the economies but could be a good indicator of the under/over valuation of the currency and the future direction of the exchange rate. Comparing these two indices leads to interesting reasoning, pointing out the theoretically more suitable measure of PPP in accordance to its propositions.

As mentioned, back in 1986 Big Mac was chosen to be a suitable measure of currency over/under evaluation due to fact that it is a homogenous good with uniform composition made according to the same recipe defined by UN Standard International Trade Classification (SITC) (Pakko and Pollard, 1996). Sold all around the world and despite the fact that is not a tradable good itself, it fits to the proposition as all of its ingredients although perishable (beef, lettuce, bread, sesame seeds) are tradable (Soo, 2016). On the other side 
Apple products are completely tradable, non-perishable goods, manufactured by the same producer in China and Taiwan, shipped and sold with same features across the world. While McDonald's operates on foreign markets mostly through franchising agreements Apple has stores in 20 countries and online stores in 39 countries. All the products are fully tradable goods, with completely identical structure on all selling points globally, easily prone to arbitrage in case of significant pricing to market. While prices of both goods also have non-tradable components such as wages, rents and utilities of restaurants and stores (Haidar, 2011). Big Mac price is considered to contain significantly higher non-trading price component with most of its ingredients locally supplied to avoid trade restrictions. As being a high-tech device, significant share of price is due to physical components of each product, but other tradable goods factors such as duties, tariffs, legal restrictions and taxes surely influence the final price in each country, which is to be examined. Also telecommunication operators bargainings reflecting the market position might influence the price of iPhones significantly, while should not have significant influence on other products indices.

Apple products are regarded to be a status symbol and tough could be more prone to pricing to market. But at the same time pricing to market is harder due to thoughtfully purchasing it as being significantly more expensive than the burger and exploitation of different purchase possibilities from easily getting the product across the border, through different channels as through online stores or through tourist migrations around the world. Due to the price level and specific features, which one uses for a longer period of time, the price is more considered upon purchase, increasing the arbitrage influence on prices. It is easier to detect the transport costs affecting the price, as well as other tradable components such as tariffs, legal restrictions and taxes than in the case of BMI where we do not know from where the exact ingredient comes from. Also Apple indices can be calculated more than twice a year, with the prices around the world available almost daily, in order not to coincide with transitory exchange rate fluctuations that do not reflect exchange rate through the year, what is not taken into account with the BMI (Kitamura and Fujiki, 2004).

\section{METHODOLOGY AND DATA}

In order to calculate Apple indices, data on prices of Apple's products in national currencies are provided from the Apple Compass web page ${ }^{4}$. Data on actual Exchange rates (currency per U.S. dollar) are provided from the Current and Historical Rate Tables ${ }^{5}$ with the date January 1 2017. The sample comprises of 37 countries (including USA as a reference country). Apple implied (real) PPP is calculated using equation 4:

$$
E_{\text {Apple }}^{\text {PPP }}=\frac{P_{\text {Apple }}}{P_{\text {Apple }}^{*}}
$$

where $E_{\text {Apple }}^{P P P}$ is Apple implied PPP exchange rate, $P_{\text {Apple }}$ is domestic Apple product price and $P_{\text {Apple }}^{*}$ is US Apple product price. Valuation from Apple indices is calculated using equation 5:

\footnotetext{
Data are available at: https://www.applecompass.com/. Available at: http://www.xe.com/currencytables.
} 


$$
\text { Valuation }_{\text {Apple }}=\left(\frac{P_{\text {Apple }}}{P_{\text {Apple }}^{*} \cdot E}\right) \cdot 100
$$

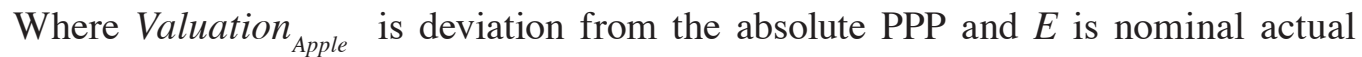
exchange rate. If nominal exchange rate is equal to the Apple implied PPP exchange rate, the absolute PPP hold. If PPP does not hold, overvaluation or undervaluation of domestic currency against the US dollar occurs. If the price ratio exceeds the nominal exchange rate, domestic currency is overvalued against the US dollar and vice versa. Data on valuation from Big Mac are taken from The Economist page Interactive currency comparison tool ${ }^{6}$.

In order to investigate key variables that affect the valuation of national currencies against the dollar, respectively testing the LOP, cross-country regression model is formulated for January 2017. Explanatory variables included in the analysis are distance, GDP, customs and duties and membership in regional economic integrations. Data for regression are calculated or taken from various Internet sources.

Proposed cross country regression model equation is stated as follows:

VALUATION $=\beta_{0}+\beta_{1}$ CUSTOM $_{j}+\beta_{2}$ GDP $_{j}+\beta_{3}$ DISTANCE $+\beta_{4}$ EUDummy $+\beta_{5}$ NAFTADummy

VALUATION - variable denoting the percentage of overvaluation or undervaluation of national currency relative to U.S. dollar. Positive values of variable VALUATION denotes percentage of overvaluation while negative values denotes undervaluation of national currency against the U.S. dollar.

$\mathrm{CUSTOM}_{j}$ - variable representing the $\mathrm{MFN}^{7}$ duty rate, sales taxes and additional duties and taxes of country $j^{8}$

$G D P_{j}$ - Gross Domestic Product per capita (in PPP international dollars) of country $j .{ }^{9}$

DISTANCE $E_{i j}$ - distance from United States's capital city Washington DC $i$ to $j^{\text {ih }}$ country capital city ${ }^{10}$.

EUDummy - 1 if $j^{\text {ih }}$ country is EU member country, otherwise 0.

NAFTADummy - 1 if $j^{\text {ih }}$ country is NAFTA member country, otherwise 0 .

Expected signs of regression are positive for variables CUSTOM $_{j}$ and DISTANCE $_{i j}$ and negative for variables $G D P_{j}$, EUDummy and NAFTADummy. It is expected that higher duty rates, taxes and distance (transportation costs) will increase the price of Apple products and consequently affect on overvaluation of national currencies against the US dollar. On the other side, higher levels of GDP and membership in EU and NAFTA may affect for price of Apple products to slide down.

Available at: http://www.economist.com/content/big-mac-index.

Most favoured nation duty rate is the lowest possible tariff a country can assess on another country.

Data are available on the page https://www.dutycalculator.com/sales_tax_rates_by_country/. For USA is used minimal sales tax of $0 \%$ for some states while for Canada used minimal sales tax for provinces of $5 \%$.

9 Data are available on the page https://knoema.com/sijweyg/gdp-per-capita-ranking-2016-data-and-charts.

10 Data are available on the page http://www.chemical-ecology.net/java/capitals.htm. 


\section{RESULTS AND DISCUSSION}

In Table 1 (Appendix) are presented Apple products' prices expressed in national currencies. Data are available for 37 countries with USA being the reference country and 12 different Apple products. In Table 2 (Appendix) are calculated Apple products' real exchange rates using equation 4 from the previous chapter. Apple products' absolute parity valuation is calculated using equation 5 and displayed in Table 3 (Appendix). It can be noticed that most of national currencies are under valuated against the U.S. dollar. Apple products' affordability Table 4 (Appendix) represents number of Apple's products that can be bought with country's GDP per capita. Furthermore, Apple product basket represents share of GDP per capita required to buy all 12 Apple's products. It can be noticed that purchase of Apple product basket is the most expensive in Brazil and Philippines with 283.06 percent and 206.53 percent of GDP per capita. On the other side, purchase of Apple products basket is the most affordable in Luxembourg and Singapore with less than 20 percent of GDP per capita.

In order to compare Apple indices and BMI average products' valuation for the observed period is calculated (Table 5 in Appendix). It can be noticed that Apple indices indicate undervaluation of national currencies against the dollar in the amount of 18.58 percent while BMI suggests overvaluation of national currencies against the dollar in the amount of 27.83 percent. Apple indices are shown to be more supportive to the validity of the PPP and LOP than the BMI. They are closest to PPP in 69.44 percent of cases in relation to BMI with 30.56 percent. As mentioned before, the signs of valuation are different between Apple indices and BMI. They have equal signs of valuation in only 13.88 percent of cases.

Since the two indices give opposite results, it raises question what key determinants influence valuation of national currencies. In Figure 1 (Appendix) is presented relationship between Apple products' prices and GDP per capita. It shows no or little correlation between GDP per capita and prices of Apple products. This will be subject to confirmation using cross-country OLS regression analysis. Considering that the Apple products are a tradable good, its price across different countries is affected by customs, duties and other costs. Figure 2 (Appendix) reveals relationship between customs (and duties) and prices of Apple products. It indicates positive correlation between variables, with Brazil being the outlier with the highest percentage of customs imposed to the price of imported good. Other variables included in the cross-country regression analysis, previously mentioned in the methodology and data section, are distance between USA and other countries and membership in regional economic integrations (namely EU and NAFTA)..Results of the cross-country OLS regression analysis for 6 different Apple products are presented in table 6 .

Number of observations in all regressions is 37 . Adjusted R-squared for all regressions is in the range of 0.7 to 0.8 . meaning the variation in the dependant variable is very well explained by its explanatory variables. Dependent variable in regression is VALUATION while independent variables are CUSTOM, GDP, DISTANCE, EU Dummy and NAFTA Dummy. Statistically significant independent variables in all regressions is CUSTOM under 1 percent level of significance. Other independent variables are not significant in the model. Interpretation of regression coefficient $b_{1}$, for the iPhone 7 product, is as follows: if CUSTOM increases by 1 percentage point, VALUATION will increase by 1.51 percentage points showing positive correlation between customs and duties imposed and prices of Apple products. 
Results of the empirical analysis indicate that BMI and Apple indices give completely different results. While BMI suggests that the most of national currencies are under valuated against the US dollar, Apple indices point to the conclusion that national currencies are over valuated against the dollar. The underlying point could be the fact that Big Mac is a nontradable good while Apple products are tradable internationally. Main determinants affecting Apple indices valuation are customs and duties and other costs opposed to BMI which is mainly influenced by non-tradable determinants.

\section{CONCLUSION}

This paper examines Apple products as a better solution for testing the PPP theory and approximation of the under/over evaluation of currencies than other light-hearted measures that have emerged until today. Several advantages in respect to BMI are presented, mostly regarded to its tradability, non-perishability, its compact structure and exactly the same features all around the world. Following, Apple products are more easily prone to arbitrage and would be a more proper light-hearted measure of strength of the currencies. Empirical findings point out that Apple product indices across countries show to be closer to parity in approximately 70 percent of presented cases than the BMI. Also, they give the opposing results, indicating overvaluation of dollar in most cases while the BMI points to undervaluation. Cross country OLS regression analysis pointed out to customs and duties as main determinants affecting the price deviations showing that countries level of openness to trade is the main reason for differences in prices across the world.

\section{REFERENCES:}

Annaert J. and De Ceuster M.J. (1997): The Big Mac: More than a junk asset allocator? International Review of Financial Analysis, 6(3): 179-192.

Ardeni P. (1989): Does the Law of One Price Really Hold for Commodity Prices? American Journal of Agricultural Economics, 71(3): 661-669.

Atal V. (2014): The Big Mac Index and real-income disparity. Journal of Business \& Economics Research, 12 (3):231-236.

Balassa B. (1964): The purchasing power parity doctrine: A reappraisal. Journal of Political Economics, 72(6): 584-596.

Cassel G. (1918): Abnormal deviations in international exchanges. The Economic Journal, 28 (112), 413-415.

Chen C.F., Wang C.A., Shen C.H. (2007): Does PPP hold for Big Mac price or consumer price index? Evidence from panel cointegration. Economics Bulletin, 6(16): 1-15.

Commonwealth Securities (2016): CommSec iPad/iPhone indexes: Australia slides. Available at: <https://www.commsec.com.au/content/dam/EN/ResearchNews/ECO_Insights_050916_CommSec-ipad-and-iphone-indexes.pdf >.

Crucini M. and Landry A. (2012): Accounting for Real Exchange Rates Using Micro-data. National Bureau of Economic Research, Working Paper Nr. 17812. 
Cumby R.E. (1996): Forecasting exchange rates and relative prices with the hamburger standard: Is what you want what you get with McParity? National Bureau for Economic Research, Working Paper Nr. 5675.

Da Silva S., Caetano S., Moura G. (2004): Big Mac parity, income, and trade. Economics Bulletin, 6(11): 9-25.

El Faramay S. (2016): The KFC Index Report by Sagaci Research. Sagaci Research. Available at: <http://sagaciresearch.com/kfcindex/>.

Fujiki H. and Kitamura Y. (2004): The Big Mac Standard: A statistical Illustration. Economics Bulletin, 6(13), 1-18.

Haidar J.I. (2011): Currency valuation and purchasing power parity. World Economics, 12(3): 1-12.

Isard P. (1977): How far can we push the "law of one price"? The American Economic Review, 67(5), 942-948.

Mazumder S. (2016): iPad Purchasing Parity: Farewell to the Big Mac Index. Economics Bulletin, 36(4):2128-2136.

Officer L.H. (1976): The purchasing-power-parity theory of exchange rates: A review article. Staff Papers, 23(1), 1-60.

Okun A.M., Fellner W., Wachter M. (1975): Inflation: its mechanics and welfare costs. Brookings Papers on Economic Activity, 1975(2), 351-401.

Ong L. (2003) The Big Mac Index: applications of purchasing power parity. Palgrave Macmillan, New York.

Pakko M.R. and Pollard P.S. (1996): For here or to go? Purchasing power parity and the Big Mac. Federal Reserve Bank of St. Louis Review, Jan: 3-22.

Pakko M.R. and Pollard P.S. (2003): Burgernomics: A Big Mac ${ }^{\mathrm{TM}}$ guide to purchasing power parity. Federal Reserve Bank of St. Louis Review, 85(6), 9-28.

Parsley D.C. and Wei S.J. (2007): A Prism into the PPP Puzzles: The Micro Foundations of Big Mac Real Exchange Rates. The Economic Journal, 117(523),1336-1356.

Parsley D.C., and Wei S.J. (1996): Convergence to the law of one price without trade barriers or currency fluctuations. The Quarterly Journal of Economics, 111(4): 1211-1236.

Rogoff K. (1996): The purchasing power parity puzzle. Journal of Economic Literature, 34(2): 647-668.

Samuelson P.A. (1964): Theoretical notes on trade problems. The Review of Economic and Statistics, 46(2): 145-54.

Soo K.T. (2016): Are hamburgers harmless?: the Big Mac Index in the twenty-first century. Working paper, Lancaster University, Department of Economics, Lancaster.

Taylor A.M. and Taylor M.P. (2004): The purchasing power parity debate. The Journal of Economic Perspectives, 18(4): 135-158.

The Economist (1986): On the origins of the hamburger standard Available at: <http:// www.economist.com/news/business-and-finance/21639762-our-article-1986-introducing-big-mac-index-origins-hamburger-standard>.

The Economist (2004): Burgers or Beans? Available at: <http://www.economist.com/ node/2361072> 
Table 1 Apple products' prices (in national currencies)

\begin{tabular}{|c|c|c|c|c|c|c|c|c|c|c|c|c|}
\hline Country/Product & $\begin{array}{c}\text { MacBook Air } \\
13^{* *} 256 \mathrm{~GB}\end{array}$ & \begin{tabular}{|c|} 
MacBook Pro \\
$15 * 256 \mathrm{~GB}$ \\
SDD, $16 \mathrm{~GB}$ \\
\end{tabular} & iMac $27 *$ Iris & $\begin{array}{c}\text { Mac mini 1TB } \\
\text { Fusion Drive, } \\
\text { Iris } \\
\end{array}$ & $\begin{array}{c}\text { Mac Pro } \\
\text { 256GB SSD, } \\
\text { 16GB }\end{array}$ & $\begin{array}{l}\text { iPad Pro 12** } \\
\text { 256GB Wi-fi + } \\
\text { cellular }\end{array}$ & $\begin{array}{l}\text { iPad Air } 2, \\
128 \text { GB Wi Fi } \\
\text { +cellular; }\end{array}$ & $\begin{array}{l}\text { iPad Mini } 4 \\
\text { 128GB Wifi + } \\
\text { cellular }\end{array}$ & $\begin{array}{c}\text { iPhone } 7256 \\
\text { GB } \\
\end{array}$ & $\begin{array}{c}\text { Apple watch } \\
\text { series } 2,42 \mathrm{~mm} \\
\text { waterproof }\end{array}$ & $\begin{array}{c}\text { Apple TV 4th } \\
\text { gen } 64 \mathrm{MB}\end{array}$ & $\begin{array}{c}\text { iPod Touch } \\
128 \text { GB } \\
\end{array}$ \\
\hline Australia & 1849 AUD & 3599 AUD & 3599 AUD & 1579 AUD & 6499 AUD & 1949 AUD & 889 AUD & 989 AUD & 1379 AUD & 579 AUd & 349 AUD & 579 AUD \\
\hline Austria & 1349 EUR & 2255 EUR & $2599 \mathrm{EUR}$ & 1099 EUR & 4599 EUR & $1409 \mathrm{EUR}$ & 649 EUR & 709 EUR & $1119 \mathrm{EUR}$ & $449 \mathrm{EUR}$ & 229 EUR & $469 \mathrm{EUR}$ \\
\hline Belgium & 1349 EUR & 2249 EUR & $2629 \mathrm{EUR}$ & 1099 EUR & $4649 \mathrm{EUR}$ & $1429 \mathrm{EUR}$ & 659 EUR & $719 \mathrm{EUR}$ & $1129 \mathrm{EUR}$ & $469 \mathrm{EUR}$ & $229 \mathrm{EUR}$ & $449 \mathrm{EUR}$ \\
\hline Brazil & $11499 \mathrm{BRL}$ & $18499 \mathrm{BRL}$ & $21999 \mathrm{BRL}$ & $8799 \mathrm{BRL}$ & $36999 \mathrm{BRL}$ & $10999 \mathrm{BRL}$ & $4199 \mathrm{BRL}$ & $5699 \mathrm{BRL}$ & $8505 \mathrm{BRL}$ & $3149 \mathrm{BRL}$ & $1749 \mathrm{BRL}$ & $3399 \mathrm{BRL}$ \\
\hline Canada & $1521 \mathrm{CAD}$ & $2571 \mathrm{CAD}$ & $3149 \mathrm{CAD}$ & $1259 \mathrm{CAD}$ & $4934 \mathrm{CAD}$ & $1710 \mathrm{CAD}$ & $786 \mathrm{CAD}$ & 839 CAD & $1217 \mathrm{CAD}$ & $555 \mathrm{CAD}$ & 282 CAD & $524 \mathrm{CAD}$ \\
\hline China & $8488 \mathrm{CNY}$ & $18488 \mathrm{CNY}$ & $16988 \mathrm{CNY}$ & $7188 \mathrm{CNY}$ & $28888 \mathrm{CNY}$ & $8888 \mathrm{CNY}$ & $4488 \mathrm{CNY}$ & $5188 \mathrm{CNY}$ & $6988 \mathrm{CNY}$ & $3188 \mathrm{CNY}$ & $1683 \mathrm{CNY}$ & $2988 \mathrm{CNY}$ \\
\hline Czech Republic & $36990 \mathrm{CZK}$ & $73990 \mathrm{CZK}$ & $69990 \mathrm{CZK}$ & $30990 \mathrm{CZK}$ & $125990 \mathrm{CZK}$ & $38590 \mathrm{CZK}$ & $18190 \mathrm{CZK}$ & $19590 \mathrm{CZK}$ & $27590 \mathrm{CZK}$ & $12290 \mathrm{CZK}$ & $6490 \mathrm{CZK}$ & $12790 \mathrm{CZK}$ \\
\hline Denmark & $10499 \mathrm{DKK}$ & $21099 \mathrm{DKK}$ & 19999 DKK & 8799 DKK & 35999 DKK & $10899 \mathrm{DKK}$ & $5299 \mathrm{DKK}$ & $5599 \mathrm{DKK}$ & $7599 \mathrm{DKK}$ & 3499 DKK & 1799 DKK & 3499 DKK \\
\hline Finland & 1379 EUR & $2299 \mathrm{EUR}$ & $2699 \mathrm{EUR}$ & $1129 \mathrm{EUR}$ & $4699 \mathrm{EUR}$ & 1449 EUR & 669 EUR & $729 \mathrm{EUR}$ & 1139 EUR & 479 EUR & $229 \mathrm{EUR}$ & 469 EUR \\
\hline France & $1349 \mathrm{EUR}$ & $2249 \mathrm{EUR}$ & $2599 \mathrm{EUR}$ & 1099 EUR & $4599 \mathrm{EUR}$ & $1429 \mathrm{EUR}$ & 665 EUR & 725 EUR & $1129 \mathrm{EUR}$ & 449 EUR & 229 EUR & $489 \mathrm{EUR}$ \\
\hline Germany & $1349 \mathrm{EUR}$ & 2249 EUR & $2599 \mathrm{EUR}$ & $1129 \mathrm{EUR}$ & $4599 \mathrm{EUR}$ & $1419 \mathrm{EUR}$ & 659 EUR & 717 EUR & 1119 EUR & $449 \mathrm{EUR}$ & 229 EUR & $449 \mathrm{EUR}$ \\
\hline Hong Kong & $8988 \mathrm{HKD}$ & $18588 \mathrm{HKD}$ & $17988 \mathrm{HKD}$ & $7588 \mathrm{HKD}$ & 31188 HKD & $9488 \mathrm{HKD}$ & $4888 \mathrm{HKD}$ & $5688 \mathrm{HKD}$ & $8288 \mathrm{HKD}$ & $3088 \mathrm{HKD}$ & $1588 \mathrm{HKD}$ & $3188 \mathrm{HKD}$ \\
\hline Hungary & 439990 HUF & 879990 HUF & 849990 HUF & $359990 \mathrm{HUF}$ & $1469990 \mathrm{HUF}$ & 469990 HUF & $226990 \mathrm{HUF}$ & $241990 \mathrm{HUF}$ & $333990 \mathrm{HUF}$ & 149990 HUF & $76990 \mathrm{HUF}$ & $149990 \mathrm{HUF}$ \\
\hline Ireland & $1379 \mathrm{EUR}$ & 2299 EUR & $2699 \mathrm{EUR}$ & $1129 \mathrm{EUR}$ & $4699 \mathrm{EUR}$ & $1449 \mathrm{EUR}$ & 669 EUR & 729 EUR & $1139 \mathrm{EUR}$ & 479 EUR & 229 EUR & $469 \mathrm{EUR}$ \\
\hline Italy & $1379 \mathrm{EUR}$ & $2299 \mathrm{EUR}$ & $2629 \mathrm{EUR}$ & $1129 \mathrm{EUR}$ & $4649 \mathrm{EUR}$ & $1429 \mathrm{EUR}$ & 659 EUR & 719 EUR & $1159 \mathrm{EUR}$ & $469 \mathrm{EUR}$ & 229 EUR & 469 EUR \\
\hline Japan & 147744 JPY & $257904 \mathrm{JPY}$ & 279504 JPY & 128304 JPY & 506304 JPY & 158544 JPY & $75384 \mathrm{JPY}$ & 85104 JPY & 102384 JPY & 44064 JPY & 26784 JPY & 52704 JPY \\
\hline Luxembourg & 1304 EUR & 2175 EUR & 2542 EUR & 1063 EUR & 4495 EUR & 1382 EUR & 637 EUR & 695 EUR & 1092 EUR & 453 EUR & 221 EUR & 434 EUR \\
\hline Malaysia & 5499 MYR & 11999 MYR & 10399 MYR & 4599 MYR & 18599 MYR & 5599 MYR & 2599 MYR & 2899 MYR & 4199 MYR & 1749 MYR & 949 MYR & 1599 MYR \\
\hline Mexico & $24999 \mathrm{MXN}$ & $55999 \mathrm{MXN}$ & 47999 MXN & 20799 MXN & 83999 MXN & $25799 \mathrm{MXN}$ & $12499 \mathrm{MXN}$ & 13799 MXN & $22899 \mathrm{MXN}$ & 8999 MXN & 3999 MXN & $7499 \mathrm{MXN}$ \\
\hline Netherlands & $1349 \mathrm{EUR}$ & $2249 \mathrm{EUR}$ & $2629 \mathrm{EUR}$ & $1129 \mathrm{EUR}$ & $4649 \mathrm{EUR}$ & $1429 \mathrm{EUR}$ & 659 EUR & 719 EUR & $1129 \mathrm{EUR}$ & $469 \mathrm{EUR}$ & $229 \mathrm{EUR}$ & 449 EUR \\
\hline New Zealand & 2199 NZD & 3999 NZD & 4199 NZD & 1799 NZD & 7499 NZD & 2179 NZD & 1049 NZD & 1149 NZD & 1599 NZD & 649 NZD & 399 NZD & 679 NZD \\
\hline Norway & $13690 \mathrm{NOK}$ & $24990 \mathrm{NOK}$ & $25990 \mathrm{NOK}$ & $10990 \mathrm{NOK}$ & $44990 \mathrm{NOK}$ & $13490 \mathrm{NOK}$ & $6590 \mathrm{NOK}$ & $6790 \mathrm{NOK}$ & $9590 \mathrm{NOK}$ & $4290 \mathrm{NOK}$ & $2249 \mathrm{NOK}$ & $3990 \mathrm{NOK}$ \\
\hline Philippines & 59990 PHP & 133990 PHP & 118990 PHP & 49990 PHP & 205990 PHP & 65990 PHP & 32990 PHP & 36990 PHP & 54257 PHP & 22490 PHP & 11690 PHP & 24990 PHP \\
\hline Poland & 5799 PLN & 11999 PLN & 10999 PLN & 4699 PLN & 18999 PLN & 5999 PLN & 2899 PLN & 2999 PLN & 4399 PLN & 1999 PLN & 999 PLN & 1999 PLN \\
\hline Portugal & 1380 EUR & 2300 EUR & $2699 \mathrm{EUR}$ & 1134 EUR & 4700 EUR & 1449 EUR & 669 EUR & 729 EUR & $1139 \mathrm{EUR}$ & 479 EUR & 229 EUR & 489 EUR \\
\hline Russia & 92990 RUB & 189990 RUB & 189990 RUB & 79990 RUB & 329990 RUB & 106990 RUB & 53990 RUB & 58990 RUB & 74990 RUB & 36990 RUB & 17990 RUB & 34990 RUB \\
\hline Singapore & 1618 SGD & 3388 SGD & 3388 SGD & 1348 SGD & $5688 \mathrm{SGD}$ & 1898 SGD & $888 \mathrm{SGD}$ & 1008 SGD & 1388 SGD & $588 \mathrm{SGD}$ & 318 SGD & 588 SGD \\
\hline South Korea & $1490000 \mathrm{KRW}$ & \begin{tabular}{|l}
$2990000 \mathrm{KRW}$ \\
\end{tabular} & $3090000 \mathrm{KRW}$ & $1250000 \mathrm{KRW}$ & $4890000 \mathrm{KRW}$ & $1550000 \mathrm{KRW}$ & $800000 \mathrm{KRW}$ & $880000 \mathrm{KRW}$ & $1200000 \mathrm{KRW}$ & $499000 \mathrm{KRW}$ & $243648 \mathrm{KRW}$ & $499000 \mathrm{KRW}$ \\
\hline Spain & $1349 \mathrm{EUR}$ & $2249 \mathrm{EUR}$ & $2629 \mathrm{EUR}$ & $1099 \mathrm{EUR}$ & $4649 \mathrm{EUR}$ & 1409 EUR & $649 \mathrm{EUR}$ & $709 \mathrm{EUR}$ & $1129 \mathrm{EUR}$ & $469 \mathrm{EUR}$ & $229 \mathrm{EUR}$ & $449 \mathrm{EUR}$ \\
\hline Sweden & 13295 SEK & $26995 \mathrm{SEK}$ & 24995 SEK & 10995 SEK & 43995 SEK & 13695 SEK & 6495 SEK & 6895 SEK & $9695 \mathrm{SEK}$ & 4495 SEK & 2295 SEK & 4495 SEK \\
\hline Switzerland & $1279 \mathrm{CHF}$ & $2699 \mathrm{CHF}$ & $2599 \mathrm{CHF}$ & $1099 \mathrm{CHF}$ & $4499 \mathrm{CHF}$ & $1399 \mathrm{CHF}$ & $699 \mathrm{CHF}$ & $799 \mathrm{CHF}$ & $999 \mathrm{CHF}$ & $449 \mathrm{CHF}$ & $229 \mathrm{CHF}$ & $449 \mathrm{CHF}$ \\
\hline Taiwan & 38900 TWD & 79900 TWD & 78900 TWD & 31900 TWD & 132900 TWD & 42900 TWD & 20900 TWD & 22900 TWD & 32500 TWD & 13500 TWD & 7290 TWD & 12990 TWD \\
\hline Thailand & $45900 \mathrm{THB}$ & $89900 \mathrm{THB}$ & $85900 \mathrm{THB}$ & $37900 \mathrm{THB}$ & $154900 \mathrm{THB}$ & $47900 \mathrm{THB}$ & $22400 \mathrm{THB}$ & $24900 \mathrm{THB}$ & $34500 \mathrm{THB}$ & $14900 \mathrm{THB}$ & $10500 \mathrm{THB}$ & $14500 \mathrm{THB}$ \\
\hline Turkey & 4799 TRY & 9499 TRY & 9099 TRY & 3899 TRY & 15999 TRY & 4699 TRY & 2149 TRY & 2349 TRY & 4049 TRY & 1499 TRY & 829 TRY & 1399 TRY \\
\hline United Arab Emirates & 4799 AED & $9499 \mathrm{AED}$ & $9199 \mathrm{AED}$ & 3999 AED & 15999 AED & 4799 AED & $2399 \mathrm{AED}$ & $2799 \mathrm{AED}$ & 3399 AED & $1599 \mathrm{AED}$ & $799 \mathrm{AED}$ & 1599 AED \\
\hline United Kingdom & 999GBP & 2349 GBP & $1849 \mathrm{GBP}$ & $799 \mathrm{GBP}$ & 3299 GBP & 1019 GBP & $529 \mathrm{GBP}$ & 579 GBP & $799 \mathrm{GBP}$ & 399 GBP & $169 \mathrm{GBP}$ & 329 GBP \\
\hline United States & 1199 USD & 2399 USD & 2299 USD & 999 USD & 3999 USD & 1229 USD & 629 USD & 729 USD & 849 USD & 399 USD & 199 USD & 399 USD \\
\hline
\end{tabular}


Table 2 Apple products' real exchange rates (January 2017)

\begin{tabular}{|c|c|c|c|c|c|c|c|c|c|c|c|c|}
\hline Country / Product & $\begin{array}{c}\text { MacBook Air } \\
13 * 256 \mathrm{~GB} \\
\end{array}$ & $\begin{array}{c}\text { MacBook Pro } \\
15^{* *} 256 \mathrm{~GB} \\
\text { SDD, } 16 \mathrm{~GB}\end{array}$ & iMac 27** Iris & $\begin{array}{c}\text { Mac mini 1TB } \\
\text { Fusion Drive, } \\
\text { Iris }\end{array}$ & $\begin{array}{c}\text { Mac Pro } \\
\text { 256GB SSD, } \\
\text { 16GB }\end{array}$ & $\begin{array}{c}\text { iPad Pro 12** } \\
\text { 256GB Wi-fi + } \\
\text { cellular } \\
\end{array}$ & $\begin{array}{c}\text { iPad Air 2, } \\
128 \text { GB Wi Fi } \\
\text { cellular; }\end{array}$ & $\begin{array}{c}\text { Pad Mini 4 } \\
\text { 128GB Wifi + } \\
\text { cellular }\end{array}$ & $\begin{array}{c}\text { iPhone } 7256 \\
\text { GB } \\
\end{array}$ & $\begin{array}{c}\text { Apple watch } \\
\text { series } 2,42 \mathrm{~mm} \\
\text { waterproof } \\
\end{array}$ & $\begin{array}{c}\text { Apple TV 4th } \\
\text { gen } 64 \mathrm{MB}\end{array}$ & $\begin{array}{c}\text { iPod Touch } \\
128 \text { GB }\end{array}$ \\
\hline Australia & 1.54 & 1.50 & 1.57 & 1.58 & 1.63 & 1.59 & 1.41 & 1.36 & 1.62 & 1.45 & 1.75 & 1.45 \\
\hline Austria & 1.13 & 0.94 & 1.13 & 1.10 & 1.15 & 1.15 & 1.03 & 0.97 & 1.32 & 1.13 & 1.15 & 1.18 \\
\hline Belgium & 1.13 & 0.94 & 1.14 & 1.10 & 1.16 & 1.16 & 1.05 & 0.99 & 1.33 & 1.18 & 1.15 & 1.13 \\
\hline Brazil & 9.59 & 7.71 & 9.57 & 8.81 & 9.25 & 8.95 & 6.68 & 7.82 & 10.02 & 7.89 & 8.79 & 8.52 \\
\hline Canada & 1.27 & 1.07 & 1.37 & 1.26 & 1.23 & 1.39 & 1.25 & 1.15 & 1.43 & 1.39 & 1.42 & 1.31 \\
\hline China & 7.08 & 7.71 & 7.39 & 7.20 & 7.22 & 7.23 & 7.14 & 7.12 & 8.23 & 7.99 & 8.46 & 7.49 \\
\hline Czech Republic & 30.85 & 30.84 & 30.44 & 31.02 & 31.51 & 31.40 & 28.92 & 26.87 & 32.50 & 30.80 & 32.61 & 32.06 \\
\hline Denmark & 8.76 & 8.79 & 8.70 & 8.81 & 9.00 & 8.87 & 8.42 & 7.68 & 8.95 & 8.77 & 9.04 & 8.77 \\
\hline Finland & 1.15 & 0.96 & 1.17 & 1.13 & 1.18 & 1.18 & 1.06 & 1.00 & 1.34 & 1.20 & 1.15 & 1.18 \\
\hline France & 1.13 & 0.94 & 1.13 & 1.10 & 1.15 & 1.16 & 1.06 & 0.99 & 1.33 & 1.13 & 1.15 & 1.23 \\
\hline Germany & 1.13 & 0.94 & 1.13 & 1.13 & 1.15 & 1.15 & 1.05 & 0.98 & 1.32 & 1.13 & 1.15 & 1.13 \\
\hline Hong Kong & 7.50 & 7.75 & 7.82 & 7.60 & 7.80 & 7.72 & 7.77 & 7.80 & 9.76 & 7.74 & 7.98 & 7.99 \\
\hline Hungary & 366.96 & 366.82 & 369.72 & 360.35 & 367.59 & 382.42 & 360.87 & 331.95 & 393.39 & 375.91 & 386.88 & 375.91 \\
\hline Ireland & 1.15 & 0.96 & 1.17 & 1.13 & 1.18 & 1.18 & 1.06 & 1.00 & 1.34 & 1.20 & 1.15 & 1.18 \\
\hline Italy & 1.15 & 0.96 & 1.14 & 1.13 & 1.16 & 1.16 & 1.05 & 0.99 & 1.37 & 1.18 & 1.15 & 1.18 \\
\hline Japan & 123.22 & 107.50 & 121.58 & 128.43 & 126.61 & 129.00 & 119.85 & 116.74 & 120,59 & 110.44 & 134.59 & 132.09 \\
\hline Luxembourg & 1.09 & 0.91 & 1.11 & 1.06 & 1.12 & 1.12 & 1.01 & 0.95 & 1,29 & 1.14 & 1.11 & 1.09 \\
\hline Malaysia & 4.59 & 5.00 & 4.52 & 4.60 & 4.65 & 4.56 & 4.13 & 3.98 & 4.95 & 4.38 & 4.77 & 4.01 \\
\hline Mexico & 20.85 & 23.34 & 20.88 & 20.82 & 21.01 & 20.99 & 19.87 & 18.93 & 26.97 & 22.55 & 20.10 & 18.79 \\
\hline Netherlands & 1.13 & 0.94 & 1.14 & 1.13 & 1.16 & 1.16 & 1.05 & 0.99 & 1.33 & 1.18 & 1.15 & 1.13 \\
\hline New Zealand & 1.83 & 1.67 & 1.83 & 1.80 & 1.88 & 1.77 & 1.67 & 1.58 & 1.88 & 1.63 & 2.01 & 1.70 \\
\hline Norway & 11.42 & 10.42 & 11,30 & 11.00 & 11.25 & 10.98 & 10.48 & 9.31 & 11.30 & 10.75 & 11.30 & 10.00 \\
\hline $\begin{array}{l}\text { Philippines } \\
\end{array}$ & 50.03 & 55.85 & 51.76 & 50.04 & 51.51 & 53.69 & 52.45 & 50.74 & 63.91 & 56.37 & 58.74 & 62.63 \\
\hline Poland & 4.84 & 5.00 & 4.78 & 4.70 & 4.75 & 4.88 & 4.61 & 4.11 & 5.18 & 5.01 & 5.02 & 5.01 \\
\hline Portugal & 1.15 & 0.96 & 1.17 & 1.14 & 1.18 & 1.18 & 1.06 & 1.00 & 1.34 & 1.20 & 1.15 & 1.23 \\
\hline Russia & 77.56 & 79.20 & 82.64 & 80.07 & 82.52 & 87.05 & 85.83 & 80.92 & 88.33 & 92.71 & 90.40 & 87.69 \\
\hline Singapore & 1.35 & 1.41 & 1.47 & 1.35 & 1.42 & 1.54 & 1.41 & 1.38 & 1.63 & 1.47 & 1.60 & 1.47 \\
\hline South Korea & 1242.70 & 1246.35 & 1344.06 & 1251.25 & 1222.81 & 1261.19 & 1271.86 & 1207.13 & 1413.43 & 1250.63 & 1224.36 & 1250.63 \\
\hline Spain & 1.13 & 0.94 & 1.14 & 1.10 & 1.16 & 1.15 & 1.03 & 0.97 & 1.33 & 1.18 & 1.15 & 1.13 \\
\hline Sweden & 11.09 & 11.25 & 10.87 & 11.01 & 11.00 & 11.14 & 10.33 & 9.46 & 11.42 & 11.27 & 11.53 & 11.27 \\
\hline Switzerland & 1.07 & 1.13 & 1.13 & 1.10 & 1.13 & 1.14 & 1.11 & 1.10 & 1.18 & 1.13 & 1.15 & 1.13 \\
\hline Taiwan & 32.44 & 33.31 & 34.32 & 31.93 & 33.23 & 34.91 & 33.23 & 31.41 & 38.28 & 33.83 & 36.63 & 32.56 \\
\hline Thailand & 38.28 & 37.47 & 37.36 & 37.94 & 38.73 & 38.97 & 35.61 & 34.16 & 40.64 & 37.34 & 52.76 & 36.34 \\
\hline Turkey & 4.00 & 3.96 & 3.96 & 3.90 & 4.00 & 3.82 & 3.42 & 3.22 & 4.77 & 3.76 & 4.17 & 3.51 \\
\hline United Arab Emirates & 4.00 & 3.96 & 4.00 & 4.00 & 4.00 & 3.90 & 3.81 & 3.84 & 4.00 & 4.01 & 4.02 & 4.01 \\
\hline United Kingdom & 0.83 & 0.98 & 0.80 & 0.80 & 0.82 & 0.83 & 0.84 & 0.79 & 0.94 & 1.00 & 0.85 & 0.82 \\
\hline United States & 1.00 & 1.00 & 1.00 & 1.00 & 1.00 & 1.00 & 1.00 & 1.00 & 1,00 & 1.00 & 1.00 & 1.00 \\
\hline
\end{tabular}

Source: Author s'calculations 
Table 3 Apple products' absolute parity valuation (deviations in \%)

\begin{tabular}{|c|c|c|c|c|c|c|c|c|c|c|c|c|}
\hline Country / Product & $\begin{array}{c}\text { MacBook Air } \\
13 * 256 \mathrm{~GB} \\
\end{array}$ & $\begin{array}{c}\text { MacBook Pro } \\
15^{* *} 256 \mathrm{~GB} \\
\text { SDD, } 16 \mathrm{~GB}\end{array}$ & iMac 27** Iris & $\begin{array}{c}\text { Mac mini 1TB } \\
\text { Fusion Drive, } \\
\text { Iris }\end{array}$ & $\begin{array}{c}\text { Mac Pro } \\
\text { 256GB SSD, } \\
\text { 16GB }\end{array}$ & $\begin{array}{c}\text { iPad Pro 12** } \\
\text { 256GB Wi-fi + } \\
\text { cellular } \\
\end{array}$ & $\begin{array}{c}\text { iPad Air 2, } \\
128 \text { GB Wi Fi } \\
\text { cellular; }\end{array}$ & $\begin{array}{c}\text { Pad Mini 4 } \\
\text { 128GB Wifi + } \\
\text { cellular } \\
\end{array}$ & $\begin{array}{c}\text { iPhone } 7256 \\
\text { GB } \\
\end{array}$ & $\begin{array}{c}\text { Apple watch } \\
\text { series } 2,42 \mathrm{~mm} \\
\text { waterproof } \\
\end{array}$ & $\begin{array}{c}\text { Apple TV 4th } \\
\text { gen } 64 \mathrm{MB}\end{array}$ & $\begin{array}{c}\text { iPod Touch } \\
128 \text { GB }\end{array}$ \\
\hline Australia & 13.41 & 10.33 & 15.13 & 16.24 & 19.52 & $\begin{array}{l}16.63 \\
\end{array}$ & 3.94 & $\begin{array}{l}-0.23 \\
\end{array}$ & 19.46 & 6.72 & 28.98 & 6.72 \\
\hline Austria & 19.24 & -0.38 & 19.81 & 16.59 & 21.88 & 21.50 & 9.35 & 3.07 & 39.68 & 19.26 & 21.95 & 24.57 \\
\hline Belgium & 19.24 & -0.65 & 21.19 & 16.59 & 23.20 & 23.22 & 11.03 & 4.52 & 40.93 & 24.57 & 21.95 & 19.26 \\
\hline Brazil & 185.39 & 129.47 & 184.75 & 162.10 & 175.32 & 166.32 & 98.65 & 132.63 & 198.10 & 134.85 & 161.54 & 153.50 \\
\hline Canada & -5.63 & -20.28 & 1.90 & -6.25 & -8.22 & 3.51 & -7.04 & -14.38 & 6.64 & 3.48 & 5.42 & -2.30 \\
\hline China & 2.72 & 11.82 & 7.21 & 4.40 & 4.81 & 4.93 & 3.53 & 3.26 & 19.43 & 15.93 & 22.71 & 8.66 \\
\hline Czech Republic & 20.93 & 20.90 & 19.34 & 21.60 & 23.50 & 23.09 & 13.36 & 5.34 & 27.39 & 20.74 & 27.84 & 25.66 \\
\hline Denmark & 24.72 & 25.27 & 23.90 & 25.45 & 28.22 & 26.31 & 19.99 & 9.39 & 27.48 & 24.90 & 28.76 & 24.90 \\
\hline Finland & 21.89 & 1.56 & 24.42 & 19.77 & 24.53 & 24.95 & 12.72 & 5.98 & 42.18 & 27.23 & 21.95 & 24.57 \\
\hline France & 19.24 & -0.65 & 19.81 & 16.59 & 21.88 & 23.22 & 12.04 & 5.40 & 40.93 & 19.26 & 21.95 & 29.88 \\
\hline Germany & 19.24 & -0.65 & 19.81 & 19.77 & 21.88 & 22.36 & 11.03 & 4.23 & 39.68 & 19.26 & 21.95 & 19.26 \\
\hline Hong Kong & -3.35 & -0.10 & 0.88 & -2.07 & 0.55 & -0.47 & 0.19 & 0.60 & 25.86 & -0.22 & 2.88 & 3.01 \\
\hline Hungary & 25.76 & 25.71 & 26.71 & 23.50 & 25.98 & 31.06 & 23.68 & 13.76 & 34.82 & 28.83 & 32.59 & 28.83 \\
\hline Ireland & 21.89 & 1.56 & 24.42 & 19.77 & 24.53 & 24.95 & 12.72 & 5.98 & 42.18 & 27.23 & 21.95 & 24.57 \\
\hline Italy & 21.89 & 1.56 & 21.19 & 19.77 & 23.20 & 23.22 & 11.03 & 4.52 & 44.67 & 24.57 & 21.95 & 24.57 \\
\hline Japan & 10.93 & -3.22 & 9.44 & 15.62 & 13.97 & 16.13 & 7.89 & 5.09 & 8.56 & -0.58 & 21.16 & 18.91 \\
\hline Luxembourg & 15.26 & -3.92 & 17.18 & 12.77 & 19.12 & 19.17 & 7.33 & 1.04 & 36.31 & 20.32 & 17.69 & 15.27 \\
\hline Malaysia & 4.18 & 13.61 & 2.74 & 4.57 & 5.64 & 3.48 & -6.14 & -9.67 & 12.34 & -0.43 & 8.32 & -8.97 \\
\hline Mexico & 1.69 & 13.85 & 1.83 & 1.55 & 2.45 & 2.39 & -3.08 & -7.68 & 31.55 & 10.01 & -1.99 & -8.33 \\
\hline Netherlands & 19.24 & -0.65 & 21.19 & 19.77 & 23.20 & 23.22 & 11.03 & 4.52 & 40.93 & 24.57 & 21.95 & 19.26 \\
\hline New Zealand & 29.37 & 17.58 & 28.83 & 27.02 & 32.27 & 25.06 & 17.64 & 11.18 & 32.85 & 14.73 & 41.43 & 20.04 \\
\hline Norway & 33.30 & 21.61 & 31.98 & 28.43 & 31.34 & 28.14 & 22.31 & 8.74 & 31.87 & 25.52 & 31.94 & 16.74 \\
\hline $\begin{array}{l}\text { Philippines } \\
\end{array}$ & 0.55 & 12.24 & 4.01 & 0.56 & 3.52 & 7.90 & 5.40 & 1.97 & 28.43 & 13.27 & 18.05 & 25.86 \\
\hline Poland & 15.65 & 19.60 & 14.40 & 12.47 & 13.60 & 16.72 & 10.21 & -1.63 & 23.90 & 19.80 & 20.04 & 19.80 \\
\hline Portugal & 21.98 & 1.60 & 24.42 & 20.30 & 24.56 & 24.95 & 12.72 & 5.98 & 42.18 & 27.23 & 21.95 & 29.88 \\
\hline Russia & 21.12 & 23.68 & 29.06 & 25.04 & 28.87 & 35.95 & 34.05 & 26.37 & 37.94 & 44.78 & 41.18 & 36.95 \\
\hline Singapore & -5.38 & -0.98 & 3.33 & -5.39 & -0.27 & 8.28 & -1.02 & -3.05 & 14.63 & 3.33 & 12.04 & 3.33 \\
\hline South Korea & 5.48 & 5.79 & 14.08 & 6.20 & 3.79 & 7.05 & 7.95 & 2.46 & 19.97 & 6.15 & 3.92 & 6.15 \\
\hline Spain & 19.24 & -0.65 & 21.19 & 16.59 & 23.20 & 21.50 & 9.35 & 3.07 & 40.93 & 24.57 & 21.95 & 19.26 \\
\hline Sweden & 19.89 & 21.67 & 17.56 & 19.00 & 18.95 & 20.49 & 11.65 & 2.27 & 23.47 & 21.81 & 24.70 & 21.81 \\
\hline Switzerland & 5.47 & 11.24 & 11.78 & 8.77 & 11.24 & 12.55 & 9.88 & 8.37 & 16.34 & 11.27 & 13.78 & 11.27 \\
\hline Taiwan & 1,69 & 4.39 & 7.57 & 0.09 & 4.16 & 9.41 & 4.15 & -1.54 & 19.98 & 6.05 & 14.82 & 2.04 \\
\hline Thailand & 7.70 & 5.43 & 5.12 & 6.74 & 8.98 & 9.65 & 0.19 & -3.90 & 14.33 & 5.06 & 48.45 & 2.24 \\
\hline Turkey & 18.80 & 17.52 & 17.47 & 15.84 & 18.75 & 13.48 & 1.41 & -4.36 & 41.55 & 11.51 & 23.65 & 4.07 \\
\hline United Arab Emirates & 8.98 & 7.81 & 8.95 & 8.99 & 8.93 & 6.32 & 3.85 & 4.54 & 9.01 & 9.11 & 9.32 & 9.11 \\
\hline United Kingdom & 3.90 & 22.10 & 0.29 & -0.26 & 2.87 & 3.39 & 4.88 & -0.96 & 17.36 & 24.70 & 5.90 & 2.82 \\
\hline United States & 0.00 & 0.00 & 0.00 & 0.00 & 0.00 & 0.00 & 0.00 & 0.00 & 0.00 & 0.00 & 0.00 & 0.00 \\
\hline
\end{tabular}

Source: Author s' calculations 
Table 4 Apple products' affordability (number of products per capita in one year)

\begin{tabular}{|c|c|c|c|c|c|c|c|c|c|c|c|c|c|}
\hline Country / Product & $\begin{array}{c}\text { MacBook } \\
\text { Air 13*** } \\
\text { 256GB } \\
\end{array}$ & $\begin{array}{c}\text { MacBook } \\
\text { Pro 15** } \\
\text { 256GB SDD, } \\
\text { 16 GB }\end{array}$ & $\begin{array}{c}\text { iMac } \\
27 * * \\
\text { Iris } \\
\end{array}$ & $\begin{array}{c}\text { Mac } \\
\text { mini 1TB } \\
\text { Fusion } \\
\text { Drive, Iris }\end{array}$ & $\begin{array}{c}\text { Mac Pro } \\
\text { 256GB } \\
\text { SSD, } \\
\text { 16GB } \\
\end{array}$ & $\begin{array}{l}\text { iPad Pro 12** } \\
\text { 256GB Wi-fi + } \\
\text { cellular }\end{array}$ & $\begin{array}{l}\text { iPad Air } \\
2,128 \\
\text { GB Wi Fi } \\
\text { +cellular: }\end{array}$ & $\begin{array}{c}\text { iPad Mini } \\
4 \text { 128GB } \\
\text { Wifi }+ \\
\text { cellular }\end{array}$ & $\begin{array}{c}\text { iPhone } \\
7256 \\
\text { GB }\end{array}$ & $\begin{array}{c}\text { Apple } \\
\text { watch series } \\
2,42 \mathrm{~mm} \\
\text { waterproof }\end{array}$ & $\begin{array}{l}\text { Apple } \\
\text { TV 4th } \\
\text { gen 64 } \\
\text { MB }\end{array}$ & \begin{tabular}{c|} 
iPod \\
Touch \\
128 \\
GB \\
\end{tabular} & $\begin{array}{c}\text { Apple } \\
\text { product } \\
\text { basket (as \% } \\
\text { of GDP pc) }\end{array}$ \\
\hline Australia & 34.32 & 21.16 & 17.63 & 40.17 & 9.76 & 32.56 & 71.35 & 64.13 & 46.00 & 109.68 & 182.11 & 109.68 & $36.62 \%$ \\
\hline Austria & 33.35 & 19.95 & 17.31 & 40.94 & 9.78 & 31.93 & 69.36 & 63.47 & 45.97 & 100.12 & 196.13 & 95.90 & $37.33 \%$ \\
\hline Belgium & 31.28 & 18.76 & 16.05 & 38.39 & 9.07 & 29.53 & 64.02 & 58.67 & 42.66 & 89.94 & 183.94 & 93.89 & $40.10 \%$ \\
\hline Brazil & 4.05 & 3.10 & 2.12 & 5.29 & 1.26 & 4.23 & 11.09 & 8.17 & 5.63 & 14.78 & 26.59 & 13.69 & $283.06 \%$ \\
\hline Canada & 39.83 & 23.56 & 19.23 & 48.12 & 12.28 & 35.41 & 77.07 & 72.25 & 49.77 & 109.06 & 214.07 & 115.60 & $31.94 \%$ \\
\hline China & 12.47 & 7.40 & 6.23 & 14.72 & 3.66 & 11.90 & 23.58 & 20.40 & 15.14 & 33.17 & 62.95 & 35.38 & $103.26 \%$ \\
\hline Czech Republic & 22.87 & 13.64 & 12.09 & 27.30 & 6.71 & 21.91 & 46.53 & 43.20 & 30.65 & 68.78 & 130.29 & 66.18 & $54.56 \%$ \\
\hline Denmark & 31.11 & 18.67 & 16.33 & 37.13 & 9.08 & 29.97 & 61.64 & 58.33 & 42.99 & 93.39 & 181.33 & 93.39 & $40.10 \%$ \\
\hline Finland & 28.50 & 17.09 & 14.56 & 34.81 & 8.36 & 27.13 & 58.73 & 53,88 & 39.33 & 81.99 & 171.36 & 83.79 & $43.84 \%$ \\
\hline France & 29.54 & 17.71 & 15.33 & 36.26 & 8.66 & 27.88 & 59.95 & 54.97 & 40.29 & 88.67 & 173.71 & 81.51 & $42.34 \%$ \\
\hline Germany & 33.58 & 20.14 & 17.43 & 40.12 & 9.85 & 31.91 & 68.74 & 63.16 & 46.29 & 100.82 & 197.50 & 100.82 & $37.15 \%$ \\
\hline Hong Kong & 50.17 & 29.49 & 25.06 & 59.40 & 14.46 & 47.50 & 92.21 & 79.26 & 62.74 & 145.97 & 283.39 & 141.35 & $25.77 \%$ \\
\hline Hungary & 17.96 & 10.83 & 9.30 & 21.96 & 5.38 & 16.82 & 34.84 & 32.67 & 23.66 & 52.73 & 102.68 & 52.73 & $69.58 \%$ \\
\hline Ireland & 47.29 & 28.36 & 24.16 & 57.76 & 13.88 & 45.02 & 97.44 & 89.40 & 65.26 & 136.03 & 284.32 & 139.03 & $26.42 \%$ \\
\hline Italy & 24.75 & 14.85 & 12.98 & 30.24 & 7.34 & 23.89 & 51.80 & 47.47 & 33.50 & 72.77 & 148.83 & 72.77 & $50.03 \%$ \\
\hline Japan & 29.99 & 20.64 & 15.86 & 34.54 & 8.75 & 27.96 & 58.75 & 52.07 & 43.31 & 100.50 & 165.51 & 84.00 & $41.10 \%$ \\
\hline Luxembourg & 73.44 & 44.05 & 37.70 & 90.21 & 21.32 & 69.34 & 150.35 & 137.75 & 100.23 & 211.49 & 431.93 & 220.64 & $17.07 \%$ \\
\hline Malaysia & 22.29 & 14.29 & 11.68 & 26.42 & 6.53 & 21.70 & 46.71 & 41.90 & 28.94 & 69.48 & 127.86 & 75.86 & $55.28 \%$ \\
\hline Mexico & 15.32 & 8.33 & 7.98 & 18.40 & 4.56 & 14.84 & 30.62 & 27.74 & 19.06 & 42.58 & 95.76 & 51.12 & $82,64 \%$ \\
\hline Netherlands & 35.43 & 21.25 & 18.18 & 42.34 & 10.28 & 33.45 & 72.53 & 66.47 & 48.33 & 101.90 & 208.39 & 106.37 & $35.46 \%$ \\
\hline New Zealand & 23.29 & 15.76 & 12.19 & 28.46 & 6.83 & 23.50 & 48.83 & 44.55 & 32.02 & 78.95 & 128.40 & 75.42 & $52.04 \%$ \\
\hline Norway & 42.18 & 26.86 & 22.21 & 52.54 & 12.83 & 42.80 & 87.61 & 85.03 & 60.21 & 134.56 & 256.65 & 144.67 & $28.43 \%$ \\
\hline Philippines & 6.41 & 3.50 & 3.23 & 7.70 & 1.87 & 5.83 & 11.66 & 10.40 & 7.09 & 17.10 & 32.89 & 15.39 & $206.53 \%$ \\
\hline Poland & 19.45 & 11.87 & 10.26 & 24.00 & 5.94 & 18.80 & 38.93 & 37.60 & 25.64 & 56.45 & 113.12 & 56.45 & $63.20 \%$ \\
\hline Portugal & 19.42 & 11.65 & 9.93 & 23.64 & 5.70 & 18.50 & 40.05 & 36.75 & 26.83 & 55.91 & 116.87 & 54.84 & $64.38 \%$ \\
\hline Russia & 16.09 & 9.18 & 7.87 & 18.70 & 4.53 & 13.98 & 27.72 & 25.35 & 19.95 & 40.42 & 83.15 & 42.73 & $82.96 \%$ \\
\hline Singapore & 76.45 & 44.36 & 36.50 & 91.76 & 21.74 & 65.13 & 139.33 & 122.65 & 89.13 & 210.34 & 388.76 & 210.34 & $17.39 \%$ \\
\hline South Korea & 29.08 & 18.13 & 14.02 & 34.66 & 8.86 & 27.96 & 54.21 & 49.22 & 36.11 & 86.84 & 178.16 & 86.84 & $43.34 \%$ \\
\hline Spain & 25.40 & 15.23 & 13.03 & 31.18 & 7.37 & 24.32 & 52.83 & 48.34 & 34.65 & 73.05 & 149.39 & 76.26 & $49.26 \%$ \\
\hline Sweden & 33.30 & 20.12 & 17.71 & 40.26 & 10.06 & 32.32 & 68.15 & 64.18 & 45.66 & 98.57 & 192.55 & 98.57 & $36.90 \%$ \\
\hline Switzerland & 46.42 & 27.63 & 22.85 & 54.03 & 13.20 & 42.44 & 84.94 & 74.31 & 59.44 & 132.24 & 259.28 & 132.24 & $28.04 \%$ \\
\hline Taiwan & 37.78 & 23.00 & 18.62 & 46.08 & 11.06 & 34.26 & 81,55 & 64.15 & 45.21 & 108.86 & 201.65 & 113.25 & $33.79 \%$ \\
\hline Thailand & 12.84 & 7.87 & 6.86 & 15.55 & 3.80 & 12.30 & 26.31 & 23.68 & 17.07 & 39.52 & 56.12 & 40.67 & $96.58 \%$ \\
\hline Turkey & 16.17 & 9.66 & 8.53 & 19.91 & 4.85 & 16.52 & 36.09 & 33.04 & 19.17 & 51.83 & 93.57 & 55.50 & $75.77 \%$ \\
\hline United Arab Emirates & 51.76 & 31.46 & 27.00 & 62.11 & 15.53 & 51.76 & 103.51 & 88.72 & 73.11 & 155.27 & 310.53 & 155.27 & $23.87 \%$ \\
\hline United Kingdom & 34.04 & 17.91 & 18.40 & 42.56 & 10.31 & 33.37 & 64.32 & 58.72 & 42.56 & 85.20 & 201.49 & 103.44 & $37.25 \%$ \\
\hline United States & 47.78 & 28.66 & 24.92 & 57.35 & 14.33 & 46.62 & 91.09 & 78.59 & 67.48 & 143.59 & 287.91 & 143.59 & $26.06 \%$ \\
\hline
\end{tabular}

Source: Author s' calculations 
Figure 1 Apple products' prices and GDP per capita (January 2017)
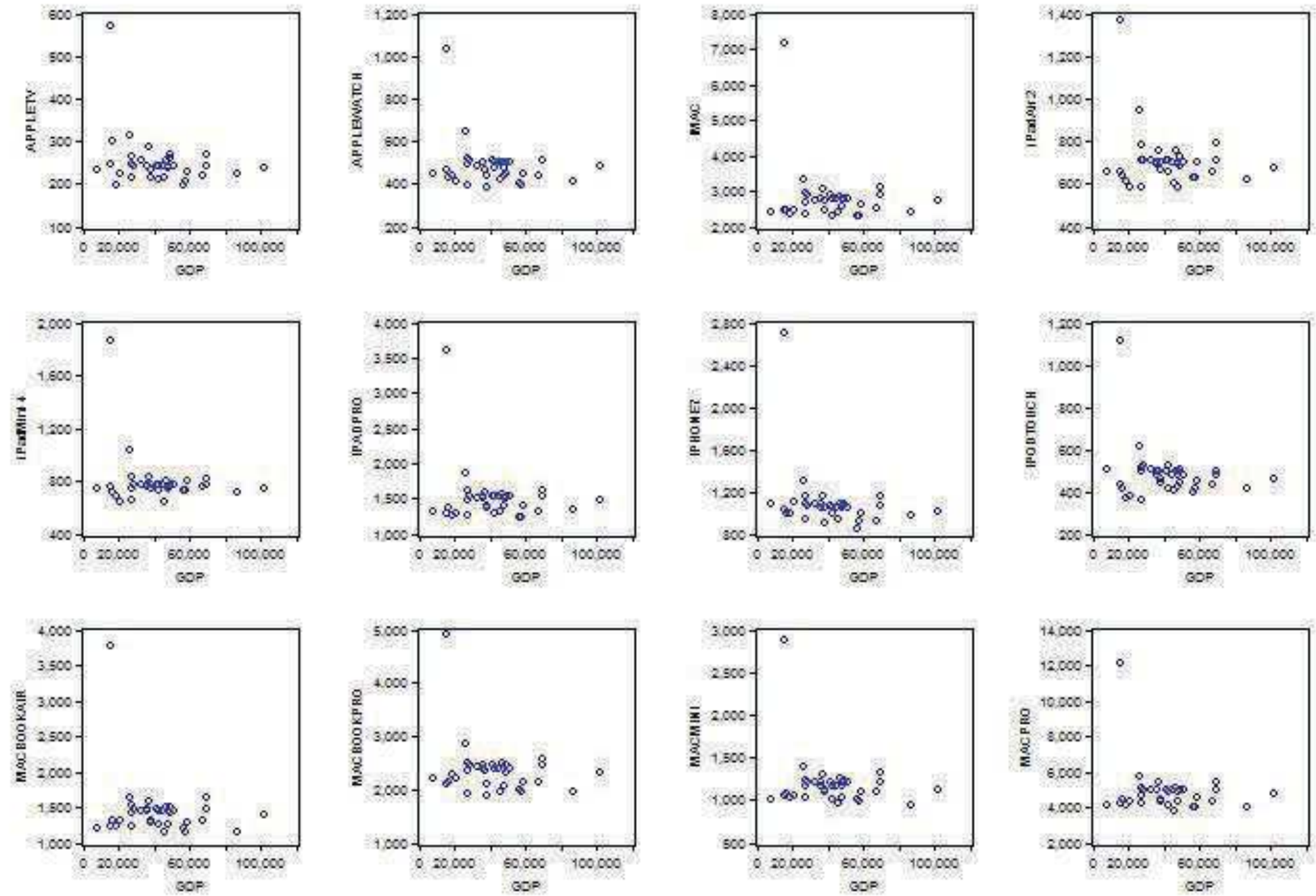

Source: Author s' calculations 

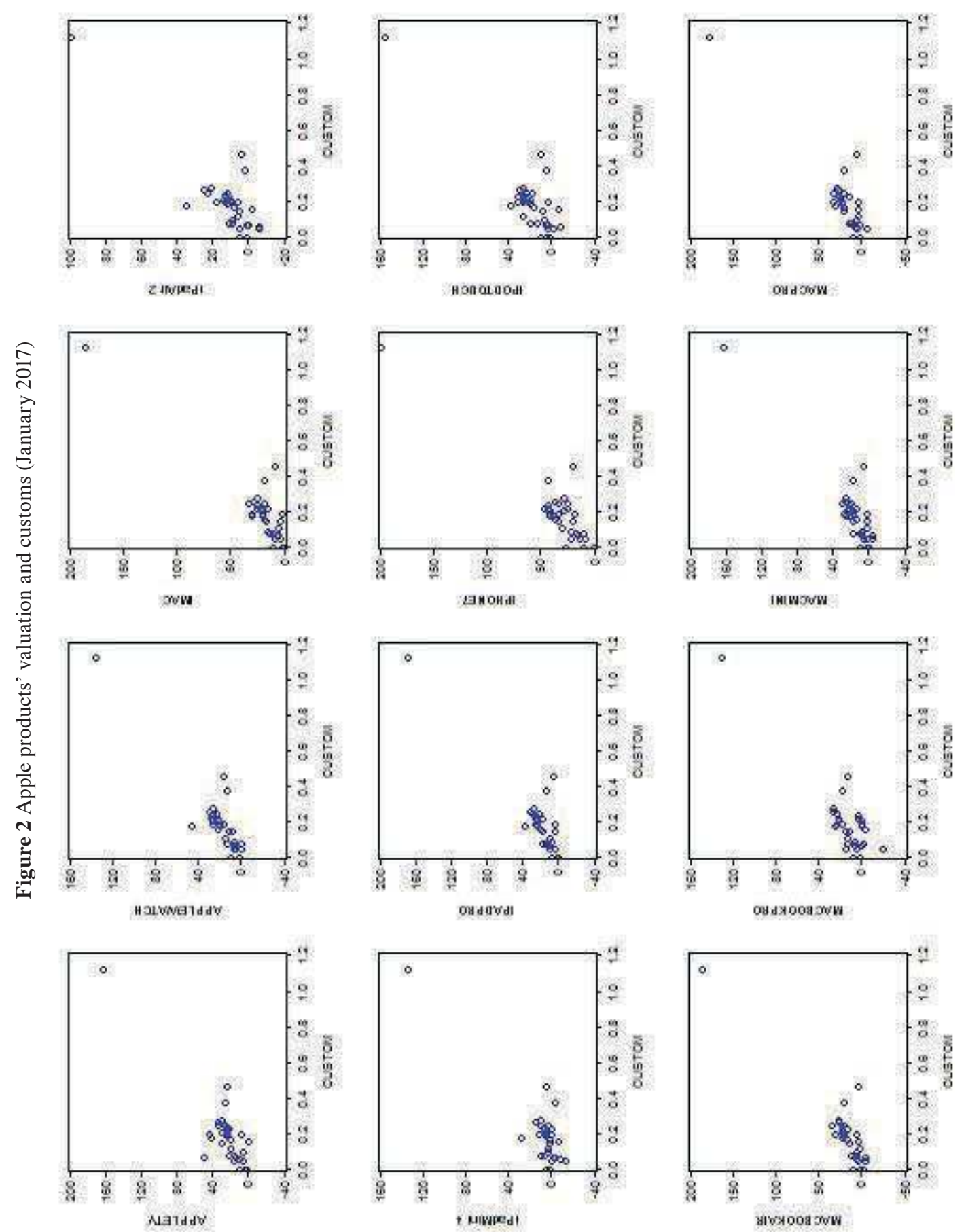

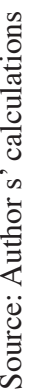


Table 5 Currency valuation comparison between BMI and average Apple index (January 2017)

\begin{tabular}{|c|c|c|c|c|}
\hline Country & $\begin{array}{c}\text { Average Apple } \\
\text { product's } \\
\text { valuation (in \%) }\end{array}$ & $\begin{array}{c}\text { Big Mac } \\
\text { valuation (in \%) }\end{array}$ & $\begin{array}{l}\text { Closest to } \\
\text { PPP }\end{array}$ & $\begin{array}{c}\text { Equal } \\
\text { signs }\end{array}$ \\
\hline Australia & 13.07 & -15.5 & Apple & $\mathrm{N}$ \\
\hline Austria & 18.04 & -29.7 & Apple & $\mathrm{N}$ \\
\hline \begin{tabular}{|l|} 
Belgium \\
\end{tabular} & 18.75 & -18.3 & $\mathrm{BM}$ & $\mathrm{N}$ \\
\hline Brazil & 156.89 & 1.1 & $\mathrm{BM}$ & $\mathrm{Y}$ \\
\hline Canada & -3.60 & -10.9 & Apple & $\mathrm{Y}$ \\
\hline China & 9.12 & -44.1 & Apple & $\mathrm{N}$ \\
\hline Czech Republic & 20.81 & -42.6 & Apple & $\mathrm{N}$ \\
\hline Denmark & 24.11 & -16.5 & $\mathrm{BM}$ & $\mathrm{N}$ \\
\hline \begin{tabular}{|l|} 
Finland \\
\end{tabular} & 20.98 & -5.9 & $\mathrm{BM}$ & $\mathrm{N}$ \\
\hline France & 19.13 & -15.2 & BM & $\mathrm{N}$ \\
\hline Germany & 18.15 & -21.6 & Apple & $\mathrm{N}$ \\
\hline Hong Kong & 2.31 & -51.1 & Apple & $\mathrm{N}$ \\
\hline Hungary & 26.77 & -39.6 & Apple & $\mathrm{N}$ \\
\hline Ireland & 20.98 & -17.2 & $\mathrm{BM}$ & $\mathrm{N}$ \\
\hline Italy & 20.18 & -13.1 & $\mathrm{BM}$ & $\mathrm{N}$ \\
\hline \begin{tabular}{|l|} 
Japan \\
\end{tabular} & 10.32 & -35.6 & Apple & $\mathrm{N}$ \\
\hline Luxembourg & 14.80 & -18.95 & Apple & $\mathrm{N}$ \\
\hline Malaysia & 2.47 & -64.6 & Apple & $\mathrm{N}$ \\
\hline Mexico & 3.69 & -55.9 & Apple & $\mathrm{N}$ \\
\hline Netherlands & 19.02 & -25.3 & Apple & $\mathrm{N}$ \\
\hline New Zealand & 24.83 & -17.3 & $\mathrm{BM}$ & $\mathrm{N}$ \\
\hline \begin{tabular}{|l|} 
Norway \\
\end{tabular} & 25.99 & 12.0 & $\mathrm{BM}$ & $\mathrm{Y}$ \\
\hline Philippines & 10.15 & -47.0 & Apple & $\mathrm{N}$ \\
\hline Poland & 15.38 & -54.5 & Apple & $\mathrm{N}$ \\
\hline \begin{tabular}{|l|} 
Portugal \\
\end{tabular} & 21.48 & -36.9 & Apple & $\mathrm{N}$ \\
\hline Russia & 32.08 & -57.5 & Apple & $\mathrm{N}$ \\
\hline Singapore & 2.40 & -23.1 & Apple & $\mathrm{N}$ \\
\hline South Korea & 7.42 & -27.3 & Apple & $\mathrm{N}$ \\
\hline Spain & 18.35 & -18.3 & $\mathrm{BM}$ & $\mathrm{N}$ \\
\hline \begin{tabular}{|l} 
Sweden \\
\end{tabular} & 18.61 & 4.0 & $\mathrm{BM}$ & $\mathrm{Y}$ \\
\hline Switzerland & 11.00 & 25.5 & Apple & $\mathrm{Y}$ \\
\hline Taiwan & 6.07 & -57.3 & Apple & $\mathrm{N}$ \\
\hline Thailand & 9.17 & -33.9 & Apple & $\mathrm{N}$ \\
\hline Turkey & 14.97 & -45.7 & Apple & $\mathrm{N}$ \\
\hline United Arab Emirates & 7.91 & -30.1 & Apple & $\mathrm{N}$ \\
\hline United Kingdom & 7.25 & -26.3 & Apple & $\mathrm{N}$ \\
\hline Average valuation & $18.58 \%$ & $-27.83 \%$ & $\begin{array}{c}\text { Apple } \\
69.44 \%, \\
\text { BM } 30.56 \%\end{array}$ & $\begin{array}{c}\text { Yes } \\
13.88 \% \text {, } \\
\text { No } 86.12 \%\end{array}$ \\
\hline
\end{tabular}

Source: Author s' calculations 
Table 6 Cross-country OLS regression for Apple products (January 2017)

\begin{tabular}{|c|c|c|c|c|c|c|}
\hline \multirow{2}{*}{$\begin{array}{l}\text { Dependant variable } \\
\text { VALUATION } \\
\text { Independent variables }\end{array}$} & \multicolumn{6}{|c|}{ Product } \\
\hline & MacBook Air & iPhone7 & Apple TV & Apple Watch & iPod Touch & iPad Pro \\
\hline Constant & $\begin{array}{l}-13.56653 \\
(16.51516)\end{array}$ & $\begin{array}{c}-2.07931 \\
(17.40354)\end{array}$ & $\begin{array}{l}-3.181729 \\
(15.72860)\end{array}$ & $\begin{array}{c}8.82965 \\
(11.87814) \\
\end{array}$ & $\begin{array}{c}3.64979 \\
(16.75501)\end{array}$ & $\begin{array}{c}-5.91595 \\
(15.65192)\end{array}$ \\
\hline CUSTOM & $\begin{array}{c}1.50435 * * * \\
(0.15094) \\
\end{array}$ & $\begin{array}{c}1.51896 * * * \\
(0.15906)\end{array}$ & $\begin{array}{c}1.22701 * * * \\
(0.14375)\end{array}$ & $\begin{array}{c}1.01661 * * * \\
(0.10856)\end{array}$ & $\begin{array}{c}1.12531 * * * \\
(0.15313)\end{array}$ & $\begin{array}{c}1.29152^{* * * *} \\
(0.14305)\end{array}$ \\
\hline GDP & 0.000180 .00012 & $\begin{array}{c}0.00013 \\
(0.00013)\end{array}$ & 4.29E-05 0.00012 & $\begin{array}{l}5.86 \mathrm{E}-05 \\
(9.13 \mathrm{E}-05)\end{array}$ & $\begin{array}{l}6.03 \mathrm{E}-05 \\
(0.00012)\end{array}$ & $\begin{array}{c}0.00016 \\
(0.00012)\end{array}$ \\
\hline DISTANCE & $\begin{array}{l}-0.00032 \\
(0.00108) \\
\end{array}$ & $\begin{array}{l}-6.24 \mathrm{E}-05 \\
(0.00113) \\
\end{array}$ & $0.00055(0.00103)$ & $\begin{array}{l}-0.00118 \\
(0.00077)\end{array}$ & $\begin{array}{l}-0.00086 \\
(0.00109) \\
\end{array}$ & $\begin{array}{l}-0.00041 \\
(0.00102) \\
\end{array}$ \\
\hline EUDummy & $\begin{array}{l}-6.57854 \\
(6.71107) \\
\end{array}$ & $\begin{array}{l}-1.99338 \\
(7.07207) \\
\end{array}$ & $\begin{array}{l}-7.50432 \\
(6.39144) \\
\end{array}$ & $\begin{array}{l}-2.69255 \\
(4.82678) \\
\end{array}$ & $\begin{array}{l}-3.66186 \\
(6.80853) \\
\end{array}$ & $\begin{array}{l}-5.70905 \\
(6.36028) \\
\end{array}$ \\
\hline NAFTADummy & $\begin{array}{l}-5.19208 \\
(14.5016) \\
\end{array}$ & $\begin{array}{l}-1.14234 \\
(15.2817) \\
\end{array}$ & $\begin{array}{c}-6.71656 \\
(13.81098) \\
\end{array}$ & $\begin{array}{l}-12.35160 \\
(10.42997) \\
\end{array}$ & $\begin{array}{l}-16.44944 \\
(14.71225)\end{array}$ & $\begin{array}{l}-7.36806 \\
(13.7436) \\
\end{array}$ \\
\hline Adjusted R-squared & 0.79793 & 0.78346 & 0.75195 & 0.80732 & 0.71219 & 0.76604 \\
\hline S.E. of regression & 13.50855 & 14.23519 & 12.86518 & 9.71570 & 13.70473 & 12.80246 \\
\hline Prob. (F-statistic) & 0.00000 & 0.00000 & 0.00000 & 0.00000 & 0.00000 & 0.00000 \\
\hline Mean dependent variable & 17.98896 & 32.26649 & 23.90953 & 19.44275 & 18.46446 & 20.27153 \\
\hline S.D. dependent variable & 30.05138 & 30.59109 & 25.83164 & 22.13385 & 25.5458 & 26.46841 \\
\hline Akaike info criterion & 8.19191 & 8.29670 & 8.09432 & 7.53275 & 8.22075 & 8.08454 \\
\hline Durbin -Watson stat & 2.46454 & 1.93333 & 2.53024 & 2.21759 & 2.43285 & 2.35661 \\
\hline Observations & 37 & 37 & 37 & 37 & 37 & 37 \\
\hline
\end{tabular}

Source: Authors' calculations

OLS estimates show White heteroskedasticity-consistent standard errors and covariances; $t$-statistics in parentheses; significant at the 1 percent level: ***, at the 5 percent level: **, at the 10 percent level: *. 